\title{
A FORGOTTEN WAR: WORLD WAR I IN THE UNITED STATES
}

\author{
Una guerra olvidada: \\ La Primera Guerra Mundial en los Estados \\ Unidos
}

\author{
S. P. MacKenzie \\ Department of History \\ University of South Carolina \\ Simon-Mackenzie@sc.edu
}

This article aims to explain how and why the First World War became, and remains to this day, a forgotten war in the United States of America. It does so primarily through the lens of popular culture, examining forms of historical memory ranging from memorials and museums to Hollywood films and reenactment societies, though academic as well as popular writings are also touched on. The central premise is that while Americans wrote about and memorialised the Great War in stone and on film just as much as the rest of the Anglo-Saxon world in the inter-war decades, for the past seventy years the First World War in the USA has been eclipsed by the Second World War; a conflict much greater in scale and scope in terms of American involvement, especially in relation to military casualties. The ongoing competition for popular attention offered by the Civil War of the previous century is also noted, along with the ways in which the First World War tends to be approached in the classroom. Finally, the future prospects of World War I in American popular consciousness are examined in the context of the approaching centenary of USA entry into the conflict.

AEF; films; museums; memorials; memory.

AEF; películas; museos; monumentos conmemorativos; memoria.

Recibido: 19-11-14. Aceptado: 04-02-15

Este artículo pretende explicar cómo y por qué la Primera Guerra Mundial se convirtió en, y aún permanece hasta este día como, la guerra olvidada en los Estados Unidos de América. Esto lo haremos sobre todo a través de la lente de la cultura popular, examinando diversos modos de memoria histórica que abarcan desde monumentos conmemorativos y museos hasta películas de Hollywood

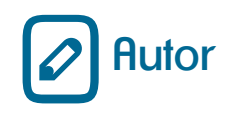

Abstract

Q Key words

Fechas

Resumen 
y asociaciones de recreación histórica, aunque también se examinarán artículos académicos y generales. La premisa principal es que mientras los americanos escribian y conmemoraban la Gran Guerra sobre piedra y carrete tanto como el resto del mundo anglosajón en las décadas entre guerras, durante los últimos setenta años en EE. UU. la Primera Guerra Mundial se ha visto eclipsada por la Segunda Guerra Mundial; un conflicto mucho mayor en escala y alcance en términos de la implicación americana, sobre todo en relación a las bajas militares. También se señalará la competición con la Guerra Civil por la atención popular a lo largo del siglo anterior, junto al modo en que la Primera Guerra Mundial tiende a abordarse en las aulas. Para terminar, el porvenir de la Primera Guerra Mundial en la conciencia americana popular se examinará dentro del contexto del próximo centenario de la entrada de EE. UU. en el conflicto.

Once upon a time the Great War, in the latter stages of which the United States participated as a co-belligerent alongside the Allies, was as well-remembered and memorialised in America as it was in Britain and the Empire. ${ }^{1}$ However, while the First World War continues to resonate today in the United Kingdom and in the parts of the Commonwealth from which contingents came to support the British cause-in-arms, a hundred years after the war began the role the United States played in it is no longer part of American public consciousness. Though academic writing on the USA and the war has been far from inconsiderable in recent decades, ${ }^{2}$ a survey conducted in 2005 of thirty-two students starting a class on the First World War at Shepherd University in West Virginia revealed that less than half of them knew who American air ace Eddie Rickenbacker was and over forty per cent did not know that John Pershing commanded the American Expeditionary Forces (AEF) (Snell, 2008, pp. 23, 26). It is telling that just two years ago the author of one of the comparatively rare popular studies of the American military experience in World War I lamented that America's wartime contribution had been more-or-less forgotten by the reading public (Rubin, 2013).

This situation also holds true in various other forms of popular culture. The biggest of the two organisations for Great War re-enactors in the United States, for instance, has a mere 450 members. ${ }^{3}$ Only three dramatic portrayals of our boys "Over There" have been screened in the past thirteen years, none of which have had much in the way of popular impact. At the start of the new millennium The Lost Battalion, based on the true story of several hundred US troops cut off for almost a week behind enemy lines, appeared on the small screen in 2001 to critical acclaim but was soon forgotten. ${ }^{4}$ Three years later Company K, a small-scale indie film adaptation of the novel by William March about his time on the Western Front with the US Marines, though admired by some who saw it, was a low-budget independent movie which had very

1 See Trout (2010) and Wingate (2005, pp. 26-47).

2 See Showalter (2003, pp. 5-13); see also, for example, D. F. Trask (2003); Ferrell (2004); Keith (2004); Roberts (2004); Grotelueschen (2007); Yockleson (2008); Simmons and Alexander (2008); Sammons (2014).

3 For more information visit "Great War Association Units".

4 According to "Lost Battalion review" (2008), The Lost Battalion had become a "greatly-overlooked" classic war film. See Lost Battalion review. 
limited distribution and did not reach a wide audience. ${ }^{5}$ Two years later Flyboys, a much bigger corporate production loosely based on the exploits of the American volunteer pilots who flew with the Lafayette Escadrille, opened in cinemas nationwide, but was panned in reviews and ended up as one of the ten biggest US box-office disasters of 2006. Meanwhile the thousands of local memorials to be found in virtually every state in the union that were built after the war go unnoticed or have fallen into disrepair, ${ }^{6}$ and there remains no national monument to World War I veterans on the Washington Mall (Chickering, 2013, p. 3).

As the editor of a collection of scholarly essays on the AEF glumly concluded a few years ago, "to the average American, the war seems irrelevant" (Snell, 2008, p. 23). But why do contemporary Americans pay so little attention to a conflict in which, albeit several generations earlier, over four million US citizens had donned a uniform? The aim of this article is to suggest reasons why, on the centenary of its outbreak, World War I remains something of a forgotten war in the United States. ${ }^{7}$

One reason why Americans know and care much less than their counterparts from other English-speaking nations about the First World War relates, of course, to the length of the fighting and the scale of the losses. Whereas the Great Powers of Europe had been fighting hard since the summer of 1914, the United States did not engage in ground combat until late in the war. The time need to recruit, equip, train, and deploy the AEF meant that it was not until late October 1917 that elements of the first division of Doughboys saw action. The AEF in France expanded massively in size, and US soldiers and marines took part in a number of defensive engagements in the spring and summer of 1918. It was not until the second week of September, however, that enough trained manpower had been deployed on the Western Front for the multi-division US First Army under the command of General John J. Pershing to engage in major offensive operations at Saint-Mihiel, and only toward the end of the month was a general advance begun in the Meuse-Argonne sector by a force that had swelled to over a million men, an offensive that would continue through the fifty-six days remaining before the Armistice came into effect. ${ }^{8}$ The battles in which Americans fought were costly. Nevertheless, the fact remains that the United States got off lightly compared to, for example, Britain and its Empire. Overall, America suffered about 51,800 killed and missing in action, or about 0.06 per cent of the population. The percentages for New Zealand, Canada, and Australia ranged from 0.8 to 1.9. For Britain itself the number killed and missing in action was 702,410, averaging out at roughly 1.5 per cent of the population. To put it another way, for the United States the cost in lives directly due to enemy action during the Great War was proportionately twenty-five times smaller than it was for the United Kingdom (Ellis \& Cox, 1993, pp. 269-70).

Along with a variety of cultural differences, this helps explain why 11 November is marked as Remembrance Day across the British Commonwealth, a date on which to soberly acknowledge and pay silent tribute at 11 a.m. local time to the uniformed personnel who died in this and subsequent wars in the service of their country, but as something quite different in the United States. Here, 11 November is a statutory public holiday: Veterans' Day. In America on this

There is not even a full inventory yet of memorials in the United States. See World War I Memorial Inventory Project

7 The phrase "forgotten war" in America is usually used in reference to the Korean War but, as Richard Rubin (2013) suggests, it could equally be applied to World War I.

8 See, for example, Ferrell (2007) and Lengel (2008).
One reason why Americans know and care much less than their counterparts from other Englishspeaking nations about the First World War relates, of course, to the length of the fighting and the scale of the losses 
date the mood is typically upbeat, the purpose being not to mourn the dead but to cheer on the living. Marked by parades and applause rather than red poppies and a minute of silence, Veterans' Day is officially a "celebration to honor America's veterans for their patriotism, love of country, and willingness to serve and sacrifice for the common good" "Histoy of Veterans Day", 2014, November 10).

Comparative scale is also important in relation to the major wars fought by Americans in the middle decades of the nineteenth century and the twentieth century. The number of American lives lost in the First World War pales in comparison to both the Civil War (approximately 620,000 dead) and the Second World War (around 407,000 dead). ${ }^{9}$ The Great War, in short, did not appear all that big when examined alongside what had come before and what would come after.

Numbers, though, only tell part of the story. After all, for over twenty years after the fighting stopped the Great War was very much a part of the American scene. The dead, as noted, were honoured around the country through stone and bronze memorials that ranged from the modest to the grandiose..$^{10}$ Among the living, ex-Doughboys began to write and publish their war stories (Capps, 2008), and collectively play a major role in forging a citizen-soldier compact with the federal state that produced first the Bonus Bill of 1924 and eventually the Serviceman's Readjustment Act, better known as the GI Bill, two decades later. ${ }^{11}$ Veterans wrote best-selling memoirs and novels. Hollywood produced a series of big-budget, star-led movies dealing with combat on or over the Western Front, including The Big Parade, Wings and What Price Glory? in the mid-1920s and The Fighting 69th and Sergeant York in the sound-era as a new war loomed closer for America. ${ }^{12}$

All that changed in the aftermath of World War II. Fatal casualties among those in the uniforms of Great Britain and the British Commonwealth were significantly lower than in World War Ilikely less than half in the case of the United Kingdom - which among other things meant that the Second World War did not displace the Great War in popular consciousness as the defining conflict of the first half of the twentieth century. In the United States, however, the reverse was true: "the First World War was eclipsed by the Second" (Snell, 2008, p. 23). For Americans, World War II had been a much larger-scale global conflict in which the United States participated for far longer and suffered much greater losses: approximately three-and-a-half times the number for World War I (Clodfelter, 1992, pp. 785, 956). Moreover, World War II seemed both more decisive in outcome and morally clear-cut than World War I appeared in retrospect. Instead of the disappointments and ambiguities of the peace settlements following the 1918 armistice, two homicidal regimes had been overthrown by force in 1945 with the United States very much in the lead, and the Japanese and (West) Germans helped on the path towards peaceful and enduring liberal democracy in the following months and years. In comparison to what had gone before, and even more so what would come after amid the frustrations of Korea

9 Wagner, Gallagher, Finkleman (2002, p. 623); Clodfelter (1992, p. 956).

10 Large-scale World War I monuments in the United States include the massive Liberty Memorial in Kansas City, MO.

11 See Keene (2003).

12 On The Big Parade (dir. K. Vidor, 1926), Wings (dir. W. A. Wellman, 1927), and What Price Glory? (dir. R. Walsh, 1926) see Suid (2002, pp. 24-41); see also Isenberg (2008). On The Fighting 69th (dir. W. Keighley, 1940) see McCabe (1997, pp. 181-183). On Sergeant York (dir. H. Hawks, 1941) see McCarthy (1997, pp. 300-318). See also Isenberg (1981) and Bridwell (2008).
The number of

American lives

lost in the First

World War pales

in comparison to

both the Civil War

(approximately

620,000 dead)

and the Second

World War (around 407,000 dead) 
and Vietnam, World War II was "the Good War" in most American minds in the second half of the twentieth century. ${ }^{13}$

From the 1940s onward it was memoirs, novels, and popular histories about World War II rather than World War I that were in vogue, and a veritable flood of profit-making war movies set in World War II streamed out of Hollywood. The tide began to ebb a little in the 1970s and 1980s, but never went away. ${ }^{14}$ Meanwhile, occasional attempts to re-inject the First World War into the war-picture mix tended to fail $;{ }^{15}$ and though it is understandable that a television biopic of Harry Truman should concentrate on his time as President of the United States, it is nonetheless noteworthy that while the biography on which the 1995 HBO film Truman was based devoted an entire chapter to his service as an AEF artillery officer (McCullough, 1992, ch. 4), this period in his life warranted a grand total of two minutes out of a total of 135 minutes screen time. ${ }^{16}$ In this same decade, moreover, as the number of living Doughboys dwindled to a handful, but legions of now-retired World War II veterans took up their pens to record their memories, efforts by slightly or much younger admirers to memorialise - indeed valorise - those who fought the good fight between 1941 and 1945, and would not be around for that much longer, developed momentum amidst growing popular support. Hence journalist Tom Brokaw's 1998 best-selling collection of personal accounts by those Americans who grew up in the 1930s and went on to win the war in the 1940s, The Greatest Generation, and director Steven Spielberg's epic big-screen version of the Normandy landings, Saving Private Ryan, both of which appeared in the late 1990s. Their immense success helped make possible the HBO television mini-series, Band of Brothers, at the start of the new century - based on a best-selling popular narrative by Stephen Ambrose first published a decade earlier - which in turn was so successful that the company went on to spend an even more lavish amount on a mini-series devoted to the island-hopping campaigns of the US Marine Corps, The Pacific, which premiered nine years later. ${ }^{17}$

These works, it should be stressed, are only among the most high-profile instances of a symbiotic relationship between the media and the populace concerning the importance of the World War II experience that dates back to the post-war decades and was, if anything, heightened around the turn of the century even as the generation which had lived it began to pass away. It was symptomatic of the extent to which World War II dominated consciousness

13 This famous phrase was used as the title of a best-selling collection of interviews, Terkel (1984), see also Bodnar (2010).

14 See Suid (2002, $64 \mathrm{ff})$

15 In the second half of the twentieth century there had been only a handful of movies featuring Americans in World War I. In the 1950s there were two remakes of films from the inter-war years, What Price Glory? (dir. J. Ford, 1952) and A Farewell to Arms (dir. C. Vidor, 1957), along with Lafayette Escadrille (dir. W. A. Wellman, 1958), none of which left a positive impression on critics or at the box office. Then at the start of the 1970s an independent film appeared, financed and directed by Donald Trumbo, based on his 1939 novel of the same name, Johnny Got His Gun, which won the special jury prize at the Cannes film festival but achieved only limited distribution in the United States and was branded in one major newspaper as "a stultifyingly bad movie" (Greenspun, 1971, August 5). Legends of the Fall (dir. E. Zwick, 1994) was much more successful at the box office, but the service in France with the Canadian Expeditionary Force of two American brothers forms only one episode in a sprawling plot. Finally, in 1996, came In Love and War (dir. R. Attenborough), based on the wartime experiences of Ernest Hemmingway that led him to write A Farewell to Arms. It was panned by critics. See e.g. Holden (1997, January 24).

16 It is also striking that in the lavish early-1990s TV adventure series, The Young Indiana Jones Chronicles, the lead character becomes a volunteer in the Belgian army during World War I rather than in the AEF.

17 See "The Pacific" and "Band of Brothers"; for a review of Band of Brothers see Cull (2002); also see Ambrose (1992).
From the 1940 s

onward it was

memoirs, novels,

and popular

histories about

World War II

rather than World

War I that were

in vogue, and a

veritable flood of

profi-making war

movies set in World

War II streamed out

of Hollymood 
of America at war in the twentieth century that when, between the appearance of Band of Brothers and The Pacific, acclaimed documentary filmmaker Ken Burns turned his attention to this period in American history, he could title the resulting public television series The War without anyone being in any doubt as to which war he meant. ${ }^{18}$ The wonder is that the World War II Historical Reenactment Society has only about two-and-a-half times the number of members as the Great War Association. ${ }^{19}$

World War II, in short, came to consume so much popular attention that the briefer, smaller, less bloody and morally less clear-cut American part in World War I was largely forgotten in popular culture. Furthermore, what limited space in public consciousness there still might have been for the Doughboys was, and continues to be, reduced by the national fascination with the war between the Union and the Confederacy. Interest came to a head in the early 1990s following the runaway success of the nine-part public television documentary series made by Ken Burns entitled The Civil War. ${ }^{20}$ The various books associated with the series became bestsellers, and the series itself was followed by Gettysburg on the big screen and further documentary series from other quarters on the small screen. In the first years of the new century the Civil War competed with World War II as a potentially lucrative subject for Hollywood producers, as the appearance of Cold Mountain and Gods and Generals attests. ${ }^{21}$ And while overall numbers are down from a peak of about 50,000, there are today still many thousands of dedicated Civil War buffs re-enacting the battles of a century-and-a-half ago. ${ }^{22}$ With so much popular attention devoted to the Civil War and World War II, there seems little or no room left for the AEF story. "Johnny Reb, Billy Yank, and the GI live forever in the American psyche”, military historian Edward G. Lengel concluded some years ago, adding pointedly that: "The Doughboy has been forgotten" (2008, p. 4).

Finally, there is the manner in which America's World War I currently features in both secondary and tertiary education in the United States. "Is there any war that has been taught in such a boring fashion?" Michael S. Neiberg, another leading military historian, recently asked rhetorically, going on to write:

Consider the focus on the trading rights of neutral nations, on President Woodrow Wilson's background, or American loans to the Allies. Then compare these dry narratives of World War I [and America] to the Civil War's drama of slavery and emancipation. Or to World War II's narrative of the Nazi threat of global conquest, America's rise to power, and the start of the Cold War. Or even to Vietnam's narrative of overreach, hubris, social discord, protest, and countercultures. (2013)

In his opinion, student interest would be much greater if the trials and tribulations of the AEF were stressed. What about the "tragic incompetence, bloody follies, and, yes, the immeasu-

18 See "The War", PBS homepage.

19 See "About us" and "Great War Association Units".

20 See "The Civil War" PBS homepage; Toplin (1996, pp. 155-83); Edgerton (2008).

21 On the Civil War and Hollywood in recent decades see, for example, Gallagher (2008, pp. 1-14, 41-134); see also, for example, Myers (2008).

22 See, for example, Melson (2012); Fastenburg (2010, July 3). Interest in the Civil War is also heightened because battlefields, cemeteries, and other pieces of "hallowed ground" can be visited more easily than sites such as the Meuse-Argonne Cemetery in France (see Snell, 2008, p. 23) though it is worth noting that distance and cost have not stopped package tour companies from successfully catering to the significant number of Americans interested in visiting D-Day sites. See, for example, Overlord Tour.
World War II, in short, came to consume so much popular attention that the briefer, smaller, less bloody and morally less clear-cut American part in World War I mas largely forgotten in popular culture 
rable courage, heroism and sacrifice?" (Neiberg, 2013, pp. 2-3). It is notable that a website supported by the National Endowment for the Humanities offering high school lesson plans provides a variety of outlines on the American road to war and the problems of peacemaking but nothing on the AEF in France. ${ }^{23}$ "Here in the United States," Neiberg argues, forcefully contrasting the situation in the USA with what is evidently the case within other participating nations, "the war remains the least-understood and most-ignored major event in our history" (Neiberg, 2013, November 15, p. 2).

There are some signs that this state of amnesia may be changing as the 100th anniversary of US entry into the Great War approaches. An old debate about whether or not the United States should have entered the war at all is showing signs of revival both online and in print. ${ }^{24}$ Moreover, it has been argued that the fact that memoirs and academic and popular books devoted to the AEF have still kept appearing in print over the last ten years or so suggests the situation is not as bad as some suggest (Trout, 2010, pp. 250-251). ${ }^{25}$ It should be remembered also that, in 2004, Congress authorised the creation of a National World War I Museum; a facility which opened with much fanfare in 2006 on part of a forty-eight acre site and has become the number-one attraction in Kansas City, Missouri. ${ }^{26}$ Meanwhile the National Museum of the Marine Corps, on which work began eleven years ago in Triangle, Virginia, has an entire gallery devoted to the USMC in World War I, and the National Museum of the United States Army, currently under construction at Fort Belvoir, Virginia, has plans for a "Nation Overseas" gallery that will encompass US army operations on foreign shores from 1898 through 1918: "The perils encountered by World War I Soldiers were unlike any the Nation had witnessed." ${ }^{27}$ In 2013, the University of North Carolina, Virginia Tech, and the American Battle Monuments Commission announced that they were partnering to create a multimedia educational programme based around the Meuse-Argonne cemetery which would help students "understand the service, experience and sacrifice of Americans that [sic] served and died during the Great War" "American scholars partner to create First World War education program", 2013). ${ }^{28}$ And in January of that year, the US government authorised the establishment of a World War I Centennial Commission.

On the other hand, it took until August 2013 for President Barack Obama to appoint the last three of the twelve centennial commissioners, and it was stressed that no taxpayer money should be involved. Meanwhile bills sponsored by individual Congressmen for a centennial coin to be minted by the Treasury Department seem to be going nowhere, and proposals made in 2008 for a national World War I monument to match those for World War II, Korea, and Vietnam in Washington, DC are still at the stage of a private group, the National World War I Memorial Foundation, soliciting individual donations and seeking to put public pressure on

23 See "History and Social Studies Lesson Plans".

24 See, for example, Pines, (2014); "Should the U.S. have entered World War I?" and "Kazin M. - Cooper, J. M. debate over U.S. entry into World War I".

25 See also, for example, Doenecke (2011); Woodward (2014).

26 For more information see "Explore Museum and Memorial".

27 See "About the Museum" National Museum of the United States Army, "Exhibits: World War I Gallery" National Museum of the Marine Corps.

28 See also "Transatlantic Teacher Scholars - American Battle Monuments Commission”.
It took until August 2013 for President Barack Obama to appoint the last three of the twelve centennial commissioners, and it mas stressed that no taxpayer money should be involved 
Congress. ${ }^{29}$ "Unlike its counterparts across the globe," Michael Neiberg recently claimed, "the United States government has done little planning for the event beyond asking the Postal Service to issue a commemorative stamp and forbidding the construction of a World War I memorial on the National Mall in Washington" (2013, p. 2). And there are now no living veterans of the Great War to make the case for the preservation of their experiences in the nation's cultural memory, the last of the Doughboys having passed away a few years ago. ${ }^{30}$ It is therefore perhaps unsurprising to find that it is a British military historian, rather than an American scholar, who is currently making the case in print for the importance of the AEF in bringing about Allied victory in $1918 .^{31}$

To conclude, it seems a safe bet that the 2017 centenary will revive interest in the Great War among the citizenry of the United States, at least in the short term. Major historical anniversaries (the ones "with a couple of zeros at the end"), after all, tend to be marked not only by special gatherings of interested academics but also by a sudden surge in media interest and coverage, much of it not all that factually sound. ${ }^{32}$ In the longer term, however, it seems likely that the combination of comparative scale and passing time will return World War I to the category of forgotten war in America.

\section{Reference list}

About the museum. (n.d.). National Museum of the United States Army. Retrieved from http:// thenmusa.org/about-the-museum.php\#side-tab6

About us. (n.d.).World War II Historical Re-enactment Society, Inc. Retrieved from http://worldwartwohrs.org/AboutUs.htm

Ambrose, S. E. (1992). Band of brothers: E company, 506th regiment, 101st airborne: from Normandy to Hitler's eagle's nest. New York: Simon and Schuster.

American scholars partner to create First World War education program. (2013, December 10). Centenary News. Retrieved from http://www.centenarynews.com/article/?id=1282

Band of Brothers. (n.d.). HBO homepage. Retrieved from http://www.hbo.com/band-ofbrothers\#/

Bodnar, J. (2010). The "good war" in American memory. Baltimore: Johns Hopkins University Press.

Bridwell, E. (2008). "After they've seen Paree": the AEF in film and music. In M. A. Snell. (Ed.), Unknown soldiers: the American expeditionary forces in memory and remembrance (pp. 238-63). Kent, OH: Kent State University Press.

Brokaw, T. (1998). The greatest generation. New York: Random House.

\footnotetext{
29 See "The Quest"; "President Obama appoints final members to USA's World War I Centennial Commission"; Capozzola (2013, p. 8); civil impulse (2015a, 2015b).

30 See also Goldstein (2011, February 28).

31 See Lloyd (2014) and Lloyd (2014, January 24).

32 See Neiberg (2013, pp. 1-2).
} 
Capozzola, C. (2013, June 22). Remembering the doughboys. OUPblog. Oxford University Press. Retrieved from http://blog.oup.com/2013/06/america-first-world-war-26-june-1917/

Capps, J. (2008). The literature of the AEF: a doughboy legacy. In M. A. Snell. (Ed.), Unknown soldiers: the American expeditionary forces in memory and remembrance (pp.195-237). Kent, OH: Kent State University Press.

Chickering, R. (2011). Why are we still interested in this old war? In J. D. Keene \& M. S. Neiberg. (Eds.), Finding common ground: new directions in first world war studies. Leiden: Brill.

Civic Impulse. (2015a). H.R. 2366 - 113th Congress: World War I American Veterans Centennial Commemorative Coin Act. Govtrack.us. Retrieved from https://www.govtrack. us/congress/bills/113/hr2366

Civic Impulse. (2015b). S. 2714 - 113th Congress: World War I American Veterans Centennial Commemorative Coin Act. Govtrack.us. Retrieved from https:/www.govtrack.us/ congress/bills/113/s2714

Civil War Casualties. (n.d.). Civil War Trust. Retrieved from http://www.civilwar.org/education/ civil-war-casualties.html

Clodfelter, M. (1992). Warfare and Armed Conflicts: A Statistical Reference, Volume II: 19001991. Jefferson, NC: McFarland.

Codefuse Studios. (2003). Company K. Retrieved from http://www.companykthefilm.com/

Company K (2004). (n.d.). IMDb. Retrieved from http://www.imdb.com/title/tt0372828/

Cull, N. J. (2002). Review of Band of Brothers mini-series. In American Historical Review, 107, pp. 991-2.

Doenecke, J. D. (2011). Nothing less than war: a new history of America's entry into world war I. Lexington, KY: University Press of Kentucky.

Edgerton, G. R. (2008). Ken Burns's rebirth of a nation: The Civil War as made-for-television history. In P. C. Rollins \& J. E. O'Conner. (Eds.), Why we fought: America's wars in film and history (pp. 99-120). Lexington, KY: University Press of Kentucky.

Ellis, J. \& Cox, M. (1993). The World War I Databook. London: Aurum.

Exhibits: World War I Gallery. (n.d.). National Museum of the Marine Corps. Retrieved from http:/www.usmcmuseum.com/exhibits_WorldWarI.asp

Explore Museum and Memorial. (n.d.). National WWI Museum at Liberty Memorial. Retrieved from https://theworldwar.org/explore/museum-and-memorial

Fastenburg, D. (2010, July 3). A brief history of civil war reenactment. Time. Retrieved from http://content.time.com/time/nation/article/0,8599,2001375,00.html

Ferrell, R. H. (2004). Collapse on the Meuse-Argonne: the failure of the Missouri-Kansas division. Columbia, MO: University of Missouri Press.

Ferrell, R. H. (2007). America's deadliest battle: the Meuse Argonne, 1918. Lawrence, KS: University Press of Kansas. 
Gallagher, G. W. (2008). Causes won, causes lost: how Hollywood and popular art shape what we know about the civil war. Chapel Hill: University of North Carolina Press.

Goldstein, R. (2011, February 28). Frank Buckles, last World War I Doughboy, is dead at 110. New York Times. Retrieved from http://www.nytimes.com/2011/03/01/us/01buckles. html

Great War Association Units. (n.d.). Great War Association. Retrieved from http://www.greatwar-assoc.org/GWAUnits.html, accessed 26 August 2014.

Greenspun, R. (1971, August 5). Movie review: Johnny Got His Gun (1971). New York Times. Retrieved from http://www.nytimes.com/movie/review?res=9E07E6DC1E3FE63ABC4 D53DFBE66838A669EDE

Grotelueschen, M. E. (2007). The AEF way of war: the American army and combat in world war I. New York: Cambridge University Press.

History and Social Studies Lesson Plans. (n.d.). EDSITEment! Retrieved from http://edsitement.neh.gov/subject/history-social-studies

History of Veterans Day. (2014, November 10). US Department of Veterans Affairs. Retrieved from http://www.va.gov/opa/vetsday/vetdayhistory.asp

Holden, S. (1997, January 24). In Love and War (1996): A Mythical Hemingway in a Blur of Muted Love. The New York Times. Retrieved from http:/www.nytimes.com/movie/revie w?res=9A07E7DF173AF937A15752C0A961958260

Isenberg, M. T. (1981). War on film: the American cinema and world war I, 1914-1941. Madison, NJ: Farleigh Dickinson University Press.

Isenberg, M. T. (2008). The great war viewed from the 1920s: The Big Parade. In P. C. Rollins \& J. E. O'Conner. (Eds.), Why we fought: America's wars in film and history (pp. 137-55). Lexington, KY: University Press of Kentucky.

Kazin, M. - Cooper, J. M. debate over U.S. entry into World War I. (2014, July 6-7). New Republic. Part 1 retrieved from http://www.newrepublic.com/article/1 18435/world-wari-debate-should-us-have-entered; part 2 retrieved from http://www.newrepublic.com/article/118436/world-war-one-should-us-have-enterered-part-2 and part 3 retrieved from http://www.newrepublic.com/article/1 18577/world-war-i-debate-europe-might-havebeen-better-if-us-sat-out

Keene, J. D. (2003). Doughboys, the great war, and the remaking of America. Baltimore: Johns Hopkins University Press.

Keith, J. (2004). Rich man's war, poor man's fight: race and class in the rural south during the first world war. Chapel Hill: University of North Carolina Press.

Laporte, N. (2006, 24 December). 2006: Hollywood diagnosis. Variety. Retrieved from http:// variety.com/2006/film/news/2006-hollywood-diagnosis-1117956263/,

Lengel, E. G. (2008). To conquer hell: the Meuse-Argonne, 1918. New York: Holt.

Lloyd, N. (2014). Hundred days: the campaign that ended world war I. New York: Basic.

Lloyd, N. (2014, January 24). How the U.S. Helped in World War I. Wall Street Journal. Retrieved from http://online.wsj.com/news/articles/SB1000142405270230463220457933 7012650058546 
Lost Battalion review. (2008). War Movie Blog. Retrieved from http://warmovieblog.com/ archives/255-the-lost-battalion-2001.html

McCabe, J. (1997). Cagney. New York: Knopf.

McCarthy, T. (1997). Howard Hawks: the grey fox of Hollywood. New York: Grove.

McCullough, D. (1992). Truman. New York: Simon and Schuster.

Melson, M. (2012). Battlefields of honor: American civil war reenactors. New York: Merrell.

Myers, R. M. (2008). "It's what people say we're fighting for": representing the lost cause in Cold Mountain. In P. C. Rollins \& J. E. O'Conner. (Eds.), Why we fought: America's wars in film and history (pp. 121-133). Lexington, KY: University Press of Kentucky.

Neiberg, M. S. (2013, November 12). Point of view: what a century! Observing the centenary of the first world war. HistoryNet. Retrieved from http://www.historynet.com/point-of-viewwhat-a-century-observing-the-centenary-of-the-first-world-war.htm

Overlord Tour. (n.d.). Retrieved from http://www.overlordtour.com/

Pierson, F. (director). (1995). Truman [movie]. USA: HBO Studios.

Pines, B. Y. (2014). America's greatest blunder: the fateful decision to enter world war one. New York: RSD.

President Obama appoints final members to USA's World War I Centennial Commission. (2013, August 12). Centenary News. Retrieved from http://www.centenarynews.com/ article/?id=1032

Roberts, F. E. (2004). The American foreign legion: black soldiers of the 93d in world war I. Annapolis: Naval Institute Press.

Rubin, R. (2013). The last of the doughboys: the forgotten generation and their forgotten war. Boston: Houghton Mifflin Harcourt.

Sammons, J. T. (2014). Harlem's rattlers and the great war: the undaunted 369th regiment and the African American quest for equality. Lawrence, KS: University Press of Kansas.

Should the U.S. have entered World War I? (n.d.). Debate.org. Retrieved from http://www.debate.org/opinions/should-the-u-s-have-entered-ww 1

Showalter, D. (2003). The United States in the great war: a historiography. OAH Magazine of History. Vol. 17, pp. 5-13.

Simmons, E. H. \& Alexander J. H. (2008). Through the wheat: the U.S. marines in world war I. Annapolis: Naval Institute Press.

Snell, M.A. (2008). "The price was made and the price was paid”: Grandpa's scar and other memories of the AEF. In M. A. Snell. (Ed.), Unknown soldiers: the American expeditionary forces in memory and remembrance. Kent, OH: Kent State University Press.

Spielberg, S. (director). (1998). Saving Private Ryan. USA: Dreamworks \& Paramount.

Suid, L. H. (2002). Guts E glory: the making of the American military image in film. Lexington, KY: University Press of Kentucky.

Terkel, S. (1984). "The good war": an oral history of world war two. New York: Pantheon. 
The Civil War. (n.d.). PBS homepage. Retrieved from http://www.pbs.org/civilwar/

The Pacific. (n.d.). HBO homepage. Retrieved from http://www.hbo.com/the-pacific\#/

The Quest. (n.d.). National World War I Memorial Foundation. Retrieved from http://wwimemorial.org/quest/

The War. (n.d.). PBS homepage. Retrieved from http://www.pbs.org/thewar/

Toplin, R. B. (Ed.). (1996). Ken Burns's The Civil War: historians respond. New York: Oxford University Press.

Transatlantic Teacher Scholars - American Battle Monuments Commission. (n.d.). Learn nc. Retrieved from http://www.learnnc.org/lp/pages/7865

Trask, D. F. (2003). The AEF and coalition warmaking, 1917-1918. Lawrence, KS: University Press of Kansas.

Trout, S. (2010). On the battlefield of memory: the first world war and American remembrance, 1919-1941. Tuscaloosa, AB: University of Alabama Press.

Wagner, M. E., Gallagher, G. W. \& Finkleman, P. (2002). The Library of Congress Civil War Desk Reference. New York: Simon and Schuster.

Wingate, J. (2005). Over the top: the doughboy in world war I memorials and visual culture. American Art. Vol. 19, pp. 26-47.

Woodward, D. R. (2014). The American army and the first world war. New York: Cambridge University Press.

World War I Memorial Inventory Project. (n.d.). Retrieved from http://wwi-inventory.org/

Yockleson, M. A. (2008). Borrowed soldiers: Americans under British command, 1918. Norman, OK: University of Oklahoma Press. 